\title{
An Analysis of the Right to Development in the Contemporary International Law
}

\author{
Benson Olukayode Omoleye Ph.D. \\ Associate Professor\& Dean of Law \\ Ekiti State University \\ Ado-Ekiti, Nigeria \\ Oluwayemi. O. Ogunkorode \\ Lecturer \\ Faculty of Law \\ Ekiti State University \\ Ado-Ekiti, Nigeria
}

\begin{abstract}
The concept of the right to development is a recent phenomenon and relatively a new addition to the family of human rights. It is a radical approach that measures development of nation-states using the indices of human rights as opposed to the traditional parameters of gross domestic product and per capita income. The development and implementation of the concept has been mired by controversies and there is wide spread skepticism about whether the right has attained the definitive status of law under the contemporary international law. This paper examines critically the concept, its development, its essential components and the challenges of its implementation.
\end{abstract}

Keywords: right to development, contemporary international law, human rights.

\section{Introduction}

The right to development is relatively a new concept. ${ }^{1}$ It is a culmination of age- long struggle and intense longing of man for self-actualization and fulfillment. As a concept, its scope and ramifications have been fairly articulated. It is the right enjoyed by all citizens of a country; it is the right to a process of development consisting of progressive realization of all recognized human rights such as social, economic, cultural, civil and political rights and other rights recognized under international law. ${ }^{2}$ The right to development is the father as it were, of all other rights. It is a core right, allencompassing as it seeks to establish socio-economic conditions for the actualization of all other rights. ${ }^{3}$ It is the precondition of liberty, progress, justice and creativity. It is the alpha and omega of human rights, the first and the last human rights, the beginning and the end, the means and the goals of human rights. ${ }^{4}$

In the right to development, human being is the object of development, the beneficiary and active participant of the right to development. It entails a process of expanding the rights and freedoms people enjoy and it is through this process that they are fully developed. It is the responsibility of the state to provide an enabling environment for the right to be realized. ${ }^{5}$

Since the second world war, an international human rights framework has been developed and has provided the UN with the authority to codify human rights, to create mechanisms to clarify the nature of states obligations and to monitor their fulfillment. ${ }^{6}$ However, bringing human rights and development together is a recent phenomenon in international law.

\footnotetext{
${ }^{1}$ First proposed by a Senegalese Jurist, Keba M'Baye in an Address to the Institute of International Law Of Human Rights In Strabourg in 1977. See K. M'baye (1982) La Driot de Development Comme, 5 Rev BRITS DE L'HOMME, 523,526

${ }^{2}$ Olive Moore, From Right to Development to Right in Development: Human Right Based Approach to development http://www.nuigalway.ie/dern/documents/54_olive_moore.pdf accessed 27 May 2017

${ }^{3}$ Nsonguru Udombana, P. Ndombana, (2003) Human Rights and Contemporary Issues in Africa. Malthouse Press Ltd, Ikeja, p. 17

${ }^{4}$ Mohammed Bedjaoui, The Right to Development in International Law: Achievement and prospects, Mohammed Bedjaoui ed, (1991)117-182; see Henry J. Philip Aston (1961), international Human Rights in context 116

${ }^{5}$ Magot E. Salomon and Arjun Sengupta, The Right to Development: Obligations of States and the Rights of Minorities and Indigenous Peoples .(Minority Rights Group International, United Kingdom 2003)P.5

${ }^{6}$ Ibid 
The growing acceptance of the relevance of human rights-based approaches to development has made the beneficiaries of development active participants of the development process by giving greater legitimacy and moral force to their demands. ${ }^{7}$ The General Assembly of the United Nations adopted the Declaration on the Right to Development (DRD) in 1986. ${ }^{8}$ It was in recognition of the fact that development is a comprehensive economic, social, cultural and political process, which aims at constant improvement of well-being of the entire population and of the individuals on the basis of their active, free and meaningful participation in development and in the fair distribution of the benefits resulting therefrom. The Declaration on the Right to Development declares that the right to development is an inalienable human right by virtue of being human and that all peoples are entitled to participate in, contribute to, and enjoy economic, social-cultural, political development in which all human rights and fundamental freedoms can be fully realized. ${ }^{9}$ It declares further that the right to development implies the full realization of the right of the people to self-determination. This includes the exercise of the inalienable right of peoples to full sovereignty over the entire natural wealth and resources. ${ }^{10}$ The right has subsequently been recognized and reaffirmed in other international legal instruments. ${ }^{11}$ The Vienna World Conference on Human Rights reaffirmed the right to development. The state is regarded as the duty bearer of the right to development. Although some of the treaty bodies and in particular the United Nations Committee on the Economic, Social and Cultural Rights have invested in elaborating extra territorial obligations of international assistance and cooperation, ${ }^{12}$ these obligations are not fully established, and hardly enforced. International human rights obligations of international organizations and private actors that have important impact on development are equally contested. ${ }^{13}$

The right to development has also found expression in some regional human right instruments. Under the African Human Rights Charter, the right is expressed as follows:

"all peoples shall have the right to their economic, social and cultural freedom and identity and in equal enjoyment of the common heritage of mankind. States shall have the duty individually and collectively to ensure the exercise of the right to development"

This paper re-examines the concept of the right to development, its essential components and appraises its significance and its practical import within the various socio-economic context, in particular the challenges, which have continually hampered its realization in concrete terms, in most jurisdictions of the world.

\section{The concept and its essential components}

In the 1980s, the emerging human right to development generated academic controversy about the content and about who owed what and to whom. ${ }^{14}$ Cynicism was expressed about the utility of expressing development needs in terms of the legal rights; doubts were voiced about the scope and judicial basis of this right as well as its prospective value for the realization of development goals whether at international or national level. ${ }^{15}$

Development is a concept of many ramifications. Socially it implies an increasing capacity to regulate both internal and external relations. ${ }^{16}$ In economic sense, it is "seen as simultaneously the vision of a better life, a life materially richer, institutionally more modern and technologically more efficient and array of means to achieve that vision" ${ }^{17}$ and at the level of individuals, it implies increased speed and capacity greater freedom, creativity, self-discipline responsibility and material well-being. ${ }^{18}$ The achievement of these aspects is very much tied to the state.

\footnotetext{
${ }^{7}$ Lanre-Helen Piron, 2002, The Right to Development : A Review of the Current State of the Debate for the Department for International Development. (2002) 7-9 http://www.odi.org/site/odi.org.uk/files/odi-assets/publications-opinion-files/2317.pdf accessed 27 May 2017

${ }^{8}$ Declaration on the Right to development, G.A.Res 41/128 annex, 41 UN GAOR Supp. (No. 53) at 186 UN

${ }^{9}$ Ibid, Article 1(1)

${ }^{10}$ ibid Article 2(2)

${ }^{11}$ The Vienna Declaration 1993, for example

${ }^{12}$ Magdalena Sepulveda, Obligations of International Assistance and Cooperation in an optional protocol to the International Covenant on Economic, Social and Cultural Right, Netherland Quarterly of Human Rights, Vol.24, (2006) P. 221-303

${ }^{13}$ See Koen De Feyter, Human Rights Social Justice in the Age of the Market (Zed publications, 2005) 238

${ }^{14}$ U. O. Umozurike, Akinola Aguda. Introduction to international Law, $3^{\text {rd }}$ ed. Spectrum Books Ltd. Nigeria, 2006, 153-154

${ }^{15} \mathrm{Ibid}$

${ }^{16}$ Nsorigurua. J. Udombana,(2003) op.cit P.3

${ }^{17}$ Dennis Goulet(1982) "Development: Creator and destroyer of values" in Human Rights in the Twenty-first Century: Aglobal Challenge, (1993) K.E Mahoney \& Paul Mahoney ed. 698-690

${ }^{18}$ Walter Rodney, (1982) How Europe Under develop Africa, Bogle-L' ouverture (publisher)
} 
Under development, on the other hand, is a series of complex interacting phenomena, resulting in flagrant inequalities of wealth and poverty, stagnation, a relative backward compared with other countries producing potentials which fail to progress as far as they might economic, cultural, political and technological dependence. ${ }^{19}$ Development is a term that deals with creation of environment in which people can develop their full potential and lead productive creative lives and as framed by key cornerstone imperative such as participation, gender and ethnic equity, the existence of peace and the rights based approach. ${ }^{20}$ As stated earlier, development has been defined as a comprehensive economic, social, political and cultural process which aims at the constant improvement of the well-being of the entire population and of all individuals on the basis of their active, free and meaningful participation in development and the distribution of the benefit resulting there from. ${ }^{21}$ The right is a human right by virtue of which every person is entitled to participate, enjoy and contribute to the cultural social, economic and political development in which all human rights and freedom can be realized. ${ }^{22}$ The integration of human right principles into the process and outcome of development programme and policies reflect in the human rights based approach to development. Human rights standards and principles are derived from international human rights instruments, which are meant to underscore all phases of development process. ${ }^{23}$ The right to development is sensitive to human development including right-based approach which takes the development formula one step further by treating all rights as integrated whole and the right to development as a comprehensive process for their achievement. ${ }^{24}$ A development process taking into account the objectives that must be achieved to realize the right to development would include for instance consideration of whether all rights are protected and promoted with respect to their indivisibility and inter-dependence. Whether all states acting at the national and international level are contributing to the accomplishment of the right and whether the procedures and outcomes are consistent with the right-based approach to development. ${ }^{25}$ The right to development includes the right to effective participation in all aspects of development, right to equal opportunity, access to resources, right to fair distribution of the benefits of development and the right to favourable environment for the realization of the right to development. ${ }^{26}$ Arjun and Sengupta defines the right to development as right to a process of development consisting of a progressive and phrased realization of all recognized human rights such as civil and political rights, economic, social and cultural rights (and other rights admitted in international law) as well as a process of economic growth consistent with human rights standards. ${ }^{27}$ The right to development is one of the controversial concepts in in contemporary human rights, the reason for its controversy centers around its meaning, implementation and justiciability. ${ }^{28}$ Bedjaoui describes the right to development as a pre-condition of liberty, progress, justice and creativity. It is the alpha and omega of human rights, the first and the last human right, the beginning and the end, the means and goals of human rights. ${ }^{29}$

The right to development is a collective right of the people. The major element of collective rights is that they protect a collective interest as opposed to individual interest. ${ }^{30}$ The right to development is often described as a collective right since they consist of numerous rights framing a collective goal.

\section{The utility of right-based approach to development}

Right-based approach to development is acclaimed to be a more effective method of ensuring a holistic improved wellbeing of people in national jurisdictions. Its utility is premised on two basic grounds- the instrumental rationale and the intrinsic rationale. ${ }^{31}$

\footnotetext{
${ }^{19}$ Yves Lacoste (1976) Geographie du-Sans Development Quoted in Bedjaoui Towards a New International Economic Order, 25(UNESCO, 1979)

${ }^{20}$ Water Rodney op.cit

${ }^{21}$ Preamble to the Declaration on the Right to Development 1986

${ }^{22}$ Article 1, Declaration on the Rights to Development 1986

${ }^{23}$ Margot. E. Salomon and Arjun Sengupta. The Right to Development and the Indigenous People (2003) op.cit ; Article 2(1) Declaration of Human Rights to Development !986

${ }^{24}$ S.Mark, The Human Rights Framework for Development: Seven Approaches . accessed 27 May 2017

${ }^{25}$ Ibid

${ }^{26}$ ibid

${ }^{27}$ Arjun Sengupta is the former UN expert on the Right to Development as a human right, an essay in commemoration of 25years of the United Nations Declaration on the Right to Development (New York and Geneva, 2013) 59

${ }^{28}$ Salim Bashir Magashi, Human Rights to Development in Nigeria, a Dissertation presented for the Degree of Doctor of Law in the Faculty of Law at Stellenbosch University 2016

${ }^{29} \mathrm{Ibid}$; M. Bedjaoui, The Right to Development in international law: Achievement and Prospects op.cit

${ }^{30}$ Nienke Van, The Right to Development and State Responsibility. (2012) 2https://www.iss.nl/fileadmin accessed 24 June 2017

${ }^{31}$ What value does a human right-based approach add to development? - hrbaportal.org 48
} 
The instrumental rationale claims that human rights approach leads to a better and more sustainable human development outcomes- ensuring women equal access to land, improved good education and emphasise the importance of civil and political rights for good governance. The approach ensures that the right of the marginalized populations and the excluded segments of the nations are protected and advanced. It ensures that the right of the otherwise neglected parts of a nation ${ }^{32}$ becomes indispensible and needed to achieve sustainable progress. The approach takes a holistic view of its environment- the family, the community, civil society, local and national authorities. It considers the social, political and legal framework that determines the relationship between those institutions and the resulting claims, duties and accountabilities. ${ }^{33}$ Human rights- based approach assists in the participatory formulation of the needed policy and legislative framework and to ensure that participatory and democratic processes are institutionalized locally and nationally (including through capacity building among families, communities and civil society to participate constructively in relevant forum. ${ }^{34}$ The approach helps to formulate policy legislations, regulations and budgets that clearly determine the particular human right(s) to be addressed-what must be done and to what standard, who is accountable- and ensures accountability of needed capacities. It helps to make the policy formulation process more transparent and empowers people and communities to hold those who have duty to act accountable, ensuring effective remedies where rights are violated. ${ }^{35}$

Human rights- based approach leads to better sustained result of development efforts and greater returns on investment, it strengthens social cohesion through seeking consensus with participatory processes and focusing assistance on the excluded and most maginalised. ${ }^{36}$ It has also been said that human rights-based approach change power dynamics in a range of ways-

a. The language of human rights can be powerful in both positive and negative ways. In some contexts, it can shut you down while in others, it can serve your cause

b. Build strategic alliance, coalition and networks with other actors who share a similar vision. ${ }^{37}$

The idea of development conceived largely in terms of all recognized human rights- civil, political, economic, social and cultural and other rights admitted in international law is certainly a much better alternative to the traditional economic model of development which employs indices or parameters, which are not all- embracing and in reality reflects or measures economic well-being of only a section of the population. Rights-based approach has been described as a right to everything, ${ }^{38}$ not realistically enforceable and at best aspirational.

\section{The Challenges of Implementing the Right to Development}

Anumber of factors have collectively worked against the realization of the right to development. From the moment of conceptualization, it has faced so many challenges. The first obstacle is that of absence of conceptual unanimity of nations on the right to development. The idea of the development being expressed in terms of legal right was not accepted by some western nations during its consideration within the United Nations General Assembly. It was caught in the web of international politics. Stephen Marks of Harvard University said in this respect:

"From the beginning the concept of the right to development has been controversial. It emerged from the legitimate preoccupation of newly interdependent countries with problems of development and the dominance of East-West issues on the agenda of the Commission of Human Rights, marginalizing the concern of the political south. Their efforts to use the United Nations to advance the idea of a New International Economic Order (NIEO) had emboldened Third World delegation. But the challenge to the prevailing order favoring first World Countries- to use the classification of the ColdWar- generated a reaction among western countries that ranged from cautious support to outright hostility for the idea of human right to development, ${ }^{, 39}$

Key western nations felt that the Declaration of the right to Development was a means of resuscitating the New International Economic Order (NIEO) which in part means an entitlement to transfer of resources; they were averse to it being made into legal obligation.

\footnotetext{
32 Ibid

${ }^{33}$ Ibid

${ }^{34}$ Ibid ; see also what are the advantages and disadvantages of a Right-based approach to poverty reduction?-P. Porto Carrero. M www.academia.edu

${ }^{35}$ What value does a human rights-based approach add to development? Op.cit

${ }^{36}$ Ibid

${ }^{37}$ ibid

${ }^{38}$ What value does a human rights-based approach add to development? Op.cit

${ }^{39}$ Stephen Marks, Obstacles to the Right to Development, www.aprmtoolkit.saii.org.za
} 
Developing countries on their part saw the right to development as being consistent with their clamor for a re-ordering of international economic order "which favored the countries of the centre to the disadvantage of those in the periphery" ${ }^{40}$ and therefore canvassed for the right to development as a means to address the imbalance. Although the United Nations Commission on Human Rights has in most documents, reaffirmed the need for an international environment which is conducive to the realization of the right to development and indeed some donor countries, international agencies and NGO seek to strengthen references to human rights in consensus documents on housing, food, security,HIV/AIDS, children, financing development and sustainable development. Some donor countries still refrain from using human right policies and language in their documents. They tend to abstain from or even oppose resolution on the right to development. These divisions and cleavages often manifest in voting in the Commission on Human Rights and the General Assembly. The Commission at its 2003 session, adopted a Resolution on the Right to Development by a vote of 47 in favour and against 3 with 3 abstentions, the United States, Australia and Japan casting a negative vote and Canada, Korea and Sweden abstaining. ${ }^{41}$

Stephen Marks has identified what he called epistemology of the right to development as yet another obstacle to its realization. According to him, not much work in terms of scholarly and empirical studies have been done to establish the relationship between development and human rights. "At conceptual level, much can be done to improve the thinking about how RTD to development relates to development and human rights theory in the scholarly community through academic publications, deliberations of learned societies and teaching in universities." He also identified lack of empirical knowledge on the nexus between human rights and development, though he conceded that some writers have done some work in this respect. ${ }^{42}$ Stephen Marks harped further on the need to stimulate scholarly debate towards this end to create and participate in panels at various professional associations of economists, political, scientist and international lawyers and international relations specialist. ${ }^{43} \mathrm{He}$ also canvassed the need to introduce the right to development issues analysis into the teaching of economic international law and related fields. ${ }^{44}$

Absence of policies at national and international level beyond lip service to the concept of the right to development is another obstacle that has been identified to the realization of the right to development. Most countries have not developed a comprehensive development policies based on the right to development frame work. They instruct their delegates to the Commission on Human Rights and the General Assembly to vote for the right to development and support the concept in speeches but "it is unlikely that the reference to right to development in these foreign policy positions has much significance as a matter of national development policy and practice" ${ }^{~} 45$ There is still this challenge of not defining mechanisms for systematic consideration of projects and polices that introduce the right to development into the development process. ${ }^{46}$ At the international level, development strategies under most international institutions have been developed with a very little concern for right to development principles. The World Bank and the IMF's Poverty Reduction Strategy Papers (PRSPS), the World Bank's Comprehensive Development Framework (CDF) and Common Country Assessment and United Nations Development Assistance Framework (CCA/UNDAF) are some of development policy approaches that though contain elements and principles that overlap with right to development, ${ }^{47}$ their conception, funding and monitoring were done outside the right to development framework. ${ }^{48}$ There is also the challenge of implementing the substantive provisions of the United Nations Declaration on the Right to Development. Article 1 of the Declaration provides:

The right to development is an alienable human right by virtue of which every human person and all the people are entitled to participate in, contribute to and enjoy economic social, cultural and political development in which all rights and fundamental freedoms can be fully realised

The right guaranteed under the Declaration as stated above straddle the whole gamut of civil and political rights, socioeconomic and cultural rights and other fundamental rights recognized in international law.

\footnotetext{
${ }^{40}$ Ibid

${ }^{41}$ Resolution 2003/83, adopted on 25 August, 2003

${ }^{42}$ Such as Philip Alton, "Making Space for Human Rights. The case of the right to development" in Harvard Human Right year book, 199=88. Pp3-40 and George Abi Saab, The legal Formulation to the Right to Development. In Rene-Jean

Dupuy)ed), The right to development at the international level, 1980, pp.163

${ }^{43}$ Stephen Marks, op.cit

${ }^{44}$ Ibid

${ }^{45} \mathrm{Ibid}$

${ }^{46} \mathrm{Ibid}$

${ }^{47}$ See Arjun Sengupta, Development cooperation and the Right to Development: An Essay in Honour of Professor Asbjourn Eide Quoted by Stephen Marks, Obstacle to the Right to Development, ibid

${ }^{48}$ Ibid 
It is quite obvious that enjoyment of these rights is largely a function of the state of the economies of nation states, and most countries particularly the developing nations do not have the economic capacity to implement socio-economic rights. Thus in most developing nations socio-economic rights are expressed as mere aspirations under their respective constitutions and not as justiciable rights. ${ }^{49}$ The rights to health, education and housing for example are not still not enforceable under the constitutions of most countries because their economies can still not shoulder these responsibilities. Commenting on the economic capacity of African nations to implement socio-economic rights, a learned writer observed:

The implementation of this obligation seems onerous for African States. Burdensome social service and ailing economics are incompatible... With a few industries and a limited wage bill, African States cannot guarantee the right to work. The bulk of the populations are peasant farmers... ${ }^{50}$

Closely related to this is the capitalist structure of the economies of some countries, which clearly do not support the enforcement of socio-economic rights. This raises once again the problem of ideological incompatibility which arosewithin the United Nations system during the conceptualization and formulation of the right to development Most of the countrieswhose economies operate on capitalist principles are unwilling to embrace social welfare programmes and policies.

Article 1(2) states that the right to development "also implies the full realization of the right of the peoples' to selfdetermination which includes subject to the relevant provisions of both International Covenant on Human Rights, the exercise of their inalienable right to full sovereignty over all natural wealth and resources"

The right to self-determination is an ambivalent concept open to so many varied interpretations, even though it is contained in landmark international instruments such as International Covenant on Civil and Political Rights (ICCPR) and International Covenant on Social, Economic and Cultural Rights (ICESCR) ${ }^{51}$ India for instance declares that the words right to self-determination appearing in those instruments apply to the people under sovereign domination and that these words do not apply to sovereign independent states. ${ }^{52}$ According to Castallino, the Resolution defines what constitutes full measure of self-government stating that it must result in a decision where people concerned vote in a free and fair election to decide whether to (a) constitute themselves as a sovereign independent state; (b) associate freely with an independent state or (c) integrate with an independent state already in existence. ${ }^{53}$

The lack of unanimity of interpretation of self-determination has not helped in the implementation of this aspect of the right development. It has created tension even instability in sovereign states where a section of the population sought to enforce right. ${ }^{54}$ It is seen as being incompatible with territorial integrity of independent sovereign state. It therefore appears that this aspect of the right to development is difficult to implement.

The other obstacle has to do with the duties imposed on states as duty-bearers under the Declaration on the Right to Development. Under the Declaration, states have the primary responsibility for the creation of national and international conditions favorable for the realization the right to development. " ${ }^{55}$ "According to the Working Group on the Implementation of the Right to Development, the responsibility of the creation of the enabling environment encompasses three main levels of (a) states acting collectively in global and regional partnerships (b) states acting individually as they adopt and implement policies that affect persons not strictly within their jurisdiction and (c) states acting individually as they formulate national development policies and programmes affecting persons within their jurisdiction. ${ }^{, 56}$ The experiences of regarding states forging regional partnerships to create enabling environment to promote economic and social development have not been free of challenges on the African continent, there is NEPADNew Partnership for African's Development.

\footnotetext{
${ }^{49}$ In Nigeria, Chapter II, section 13-18 of the 1999 Constitution of the Federal Republic of Nigeria make socio-economic rights non-justiciable also in India, Article 37-51

${ }^{50}$ Umozurike. U. O,. 2007, The African Charter on Human and Peoples' Rights, Umozurike, U. O (editor) Nigeria Institute of Advanced Legal Studies (publisher) Lagos, P.6

${ }^{51}$ There has also been notable United Nations Resoution on the Right to self-determination and Resolution 2625 in 1970 which expanded the former

${ }^{52}$ Hurst Hannum Autonomy, sovereignty, and Self-determination: The accommodation of conflicting Rights Philadelphia: University of Pennsylvania Press, 1996. Pp41-42

${ }^{53}$ Joshua Castellino, International Law and Self-determination: The Interplay of Politics of Territorial Possession with Formulations of Post-Colonial National Identity , The Haque: Martinus Nuhoff Publishers 2009, P22-23

${ }^{54}$ See Chinonso Ijezie,Right of Peoples to self-determination in the present International

Law,www.academia.edu/29b7647, available also at ssrn.corn/abstract.accessed $5^{\text {th }}$ may 2018

${ }^{55}$ Article 3

${ }^{56}$ Article 2-4
} 
The initiative, like others have suffered from lack of commitment by the state parties. Skepticism by civil society groups as another economic model prescribed western nations ${ }^{57}$ and that the process by which NEPAD was adopted was not sufficiently participatory. There has been very little done by most states in terms of developing policies and programmes based on right to development framework. At home and international levels there is still a wide gap between rhetoric's and implementation. ${ }^{58}$

\section{Assessment and conclusion}

The right to development may not have attained a definitive status of law under the contemporary international law, it is gradually evolving to be so. It is a lot better than the traditional economic model of development which does not factor in issues of human rights of the generality of people in nation-states. Its emphasis on principles of equality, nondiscrimination, participation, transparency, accountability as well as international cooperation is true and genuine indices to measured real development. Macro-economic indices of Gross Domestic Product (GDP) and Per Capital Income are jaded, archaic and does not address development in a holistic manner. Development measured in terms of human rights is all-encompassing and truly gauges progress in all ramifications. States need to do more in terms of commitment to the right both in their national and international policies and programs. National programs need to be predicated consciously on the right to development framework. More studies needs to be undertaken to establish the link between human rights and development and more sensitization and enlightenment of the people on the right to development model is highly essential. Rights to development holds a great promise of being widely accepted as a better parameters of development by the global community in the foreseeable future.

\footnotetext{
${ }^{57}$ Accra Declaration. Declaration on Africa's Development Challenges adopted at end of joint CODESRIA-TWN-AFRICA conference on African's Development challenges in the Millennium, Accra 23-26. April 2002

${ }^{58}$ Stephen Marks, Obstacles to the Right of Development,op.cit 